PNL-6745

UC-70

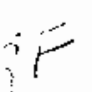

\title{
Test Plan for Thermogravimetric Analyses of BWR Spent Fuel Oxidation
}

R. E. Einziger

December 1988

Prepared for

Lawrence Livermore National Laboratory

under a Related Services Agreement

with the U.S. Department of Energy

Contract DE-AC06-76RLO 1830

Pacific Northwest Laboratory

Operated for the U.S. Department of Energy

by Battelle Memorial Institute 


\title{
DISCLAJMER
}

This report was prepared as an account of work sponsored by an agency of the United States Government. Neither the United States Government nor any agency thereof, nor Battelle Memorial Institute, nor any or their employees, makes any warranty, expressed or implied, or assumes any legal liability or responsibility for the accuracy, completeness, or usefulness of any information, apparatus, product, or process disclosed, or represents that its use would not infringe privately owned rights. Reference herein to any specific commercial product, process, or service by trade name, trademark, manufacturer, or otherwise does not necessarily constitute or imply its endorsement, recommendation, or favoring by the United States Government or any agency thereof, or Battelle Memorial Institute. The views and opinions of authors expressed herein do not necessarily state or reflect those of the United States Government or any agency thereot.

\author{
PACIFIC NORTHWEST LABORATORY \\ operated by \\ BATTELLE MEMORIAL INSTITUTE \\ for the \\ UNITED STATES DEPARTMENT OF ENERGY \\ under Contract DE-ACO6-76RLO 7830
}

\begin{tabular}{|c|c|}
\hline \multicolumn{2}{|c|}{ Printed in the United States of America } \\
\hline \multicolumn{2}{|c|}{ Available from } \\
\hline \multicolumn{2}{|c|}{ National Technical Information Service } \\
\hline \multicolumn{2}{|c|}{ United States Department of Commerce } \\
\hline \multicolumn{2}{|c|}{5285 Port Royal Road } \\
\hline \multicolumn{2}{|c|}{ Springfield, Virginia 22161} \\
\hline \multicolumn{2}{|c|}{ NTIS Price Codes } \\
\hline \multicolumn{2}{|c|}{ Microfiche A01 } \\
\hline \multicolumn{2}{|c|}{ Printed Copy } \\
\hline & Price \\
\hline Pages & Codes \\
\hline $007-025$ & $\mathrm{~A} 02$ \\
\hline $026-050$ & A03 \\
\hline $051-075$ & A04 \\
\hline $076-100$ & $\mathrm{~A} 05$ \\
\hline $101 \cdot 125$ & $A 06$ \\
\hline $126-150$ & A07 \\
\hline $151-175$ & $\mathrm{AOB}$ \\
\hline $176-200$ & AOS \\
\hline 201-225 & A10 \\
\hline $226-250$ & A11 \\
\hline $251-275$ & A12 \\
\hline $276-300$ & A13 \\
\hline
\end{tabular}


PNL -6745

UC -70

TEST PLAN FOR

THERMOGRAVIMETRIC ANALYSES

OF BWR SPENT FUEL OXIDATION

R. E. Einziger

December 1988

Prepared for

Lawrence Livermore National Laboratory

under a Related Services Agreement

with the U.S. Department of Energy

Contract OE-ACO6-76RLO 1830

Pacific Northwest Laboratory

Richland, Washington 99352 


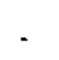

- 
Preliminary studies indicated the need for additiona? Tow-temperature spent fuel oxidation data to determine the behavior of spent fuel as a waste form for a tuff repository. Short-term thermogravimetric analysis tests were recommended in a comprehensive technical approach as the method for providing scoping data that could be used to 1) evaluate the effects of variabies such as moisture and burnup on the oxidation rate, 2) determine operative mechanisms, and 3) guide long-term, low-temperature oxidation testing. The initial test series studied the temperature and moisture effects on pressurized water reactor fuel as a function of particle and grain size. This document presents the test matrix for studying the oxidation behavior of boiling water reactor fue? in the temperature range of 140 to $225^{\circ} \mathrm{C}$. 


\section{CONTENTS}

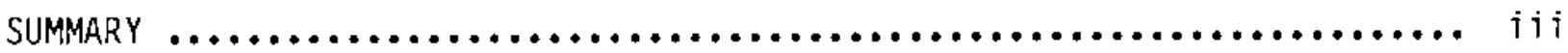

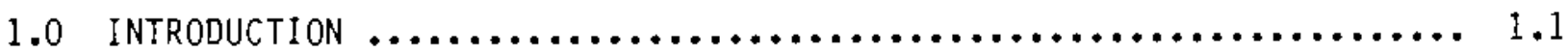

1.1 OBJeCtive Of THERMOGRAVIMETRIC ANALYSIS TESTING $\ldots \ldots \ldots \ldots \ldots . .2$

1.2 BACKGROUND $\ldots \ldots \ldots \ldots \ldots \ldots \ldots \ldots \ldots \ldots \ldots \ldots \ldots \ldots \ldots \ldots, 1.3$

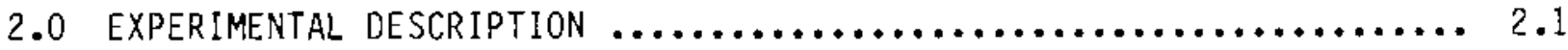

2.1 TEST MATRIX $\ldots \ldots \ldots \ldots \ldots \ldots \ldots \ldots \ldots \ldots \ldots \ldots \ldots \ldots \ldots \ldots, 2.1$

2.2 SAMPLE PREPARATION AND IDENTIfICATION $\ldots \ldots \ldots \ldots \ldots \ldots \ldots \ldots .2 .3$

2.2 .1 Test Fuel Selection $\ldots \ldots \ldots \ldots \ldots \ldots \ldots \ldots \ldots \ldots \ldots \ldots \ldots \ldots \ldots \ldots \ldots, 2.3$

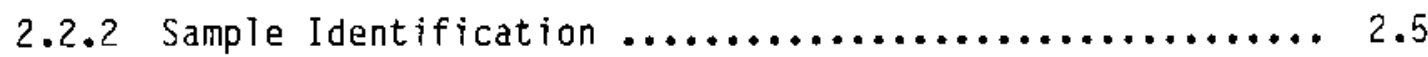

2.3 TESting ATMOSPHERE $\ldots \ldots \ldots \ldots \ldots \ldots \ldots \ldots \ldots \ldots \ldots \ldots \ldots \ldots \ldots \ldots \ldots, 2.5$

2.4 THERMOGRAVIMETRIC ANALYSIS SYSTEM $\ldots \ldots \ldots \ldots \ldots \ldots \ldots \ldots \ldots \ldots, 2.6$

2.5 POST-TEST SAMPLE AND GAS EVALUATION $\ldots \ldots \ldots \ldots \ldots \ldots \ldots \ldots \ldots . . .6$

2.5 .1 Ceramography $\ldots \ldots \ldots \ldots \ldots \ldots \ldots \ldots \ldots \ldots \ldots \ldots \ldots \ldots \ldots \ldots, 2.8$

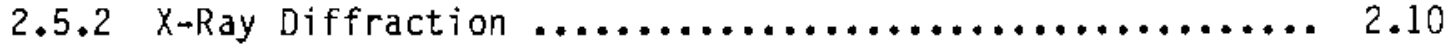

2.5.3 Scanning Electron Microscopy $\ldots \ldots \ldots \ldots \ldots \ldots \ldots \ldots \ldots . . .2 .10$

2.5 .4 Ion Microprobe $. . \ldots \ldots \ldots \ldots \ldots \ldots \ldots \ldots \ldots \ldots \ldots, 2.10$

2.5.5 Iransmission Electron Microscopy and Electron

2.5 .6 Fission Gas $\ldots \ldots \ldots \ldots \ldots \ldots \ldots \ldots \ldots \ldots \ldots \ldots \ldots \ldots, 2.12$

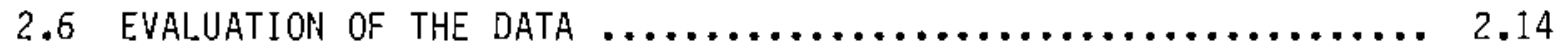

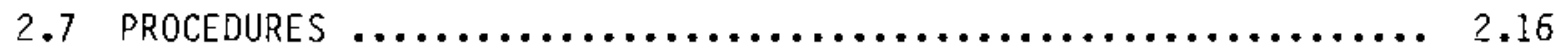

2.8 REPORTING AND DATA RECORDING $\ldots \ldots \ldots \ldots \ldots \ldots \ldots \ldots \ldots \ldots \ldots \ldots, 2.16$

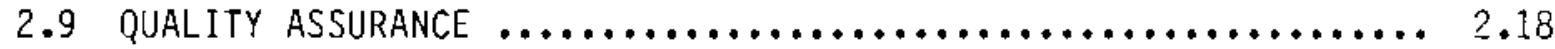

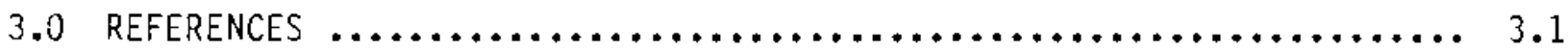




\section{FIGURES}

1.1 Technical Approach to Low-Temperature Fuel 0xidation Study ....... 1.2

2.1 Schematic of TGA System $\ldots \ldots \ldots \ldots \ldots \ldots \ldots \ldots \ldots \ldots \ldots \ldots \ldots \ldots \ldots \ldots \ldots$

2.2 As-Polished Ceramography of Oxidized Fue? Showing Widened Grain

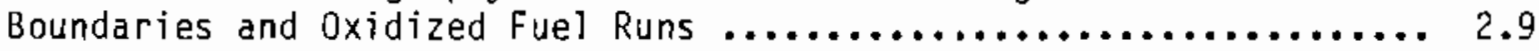

2.3180 Distribution in PWR Fuel Oxidized at $175.6^{\circ} \mathrm{C} \ldots \ldots \ldots \ldots \ldots \ldots$

2.4 Grain Boundary Region in 0xidized Fuel $\ldots \ldots \ldots \ldots \ldots \ldots \ldots \ldots \ldots \ldots \ldots$

2.5 Oxidation of Spent Turkey Point PWR Fuel in Air at $200^{\circ} \mathrm{C} \ldots \ldots \ldots . . .2 .15$

2.6 Arrhenius Plot at $\Delta(0 / M)=0.02$ for Oxidation of PWR Fuel $\ldots \ldots \ldots 2.17$

\section{TABLES}

2.1 TGA BWR Fuel Test Matrix $\ldots \ldots \ldots \ldots \ldots \ldots \ldots \ldots \ldots \ldots \ldots \ldots \ldots \ldots \ldots \ldots . \ldots 2$

2.2 Characteristics of ATM-105 Cooper BWR Fuel from General Electric ... 2.4

2.3 Exanination Procedures $\ldots \ldots \ldots \ldots \ldots \ldots \ldots \ldots \ldots \ldots \ldots \ldots \ldots \ldots \ldots \ldots \ldots \ldots . \ldots \ldots \ldots$ 


\subsection{INTRODUCTION}

The Yucca Mountain Project Office (YMPO) is evaluating Yucca Mountain, Nevada, for the U.S. Department of Energy (DOE) Office of Civilian Radioactive Waste Management (OCRWM) to determine the suitability of this site for a highlevel nuclear waste repository. The horizon that is under investigation for repository development is the Topopah Spring Member of the Paintbrush Tuff, a welded, devitrified ash flow tuff. At Yucca Mountain, this unit lies in the unsaturated zone; the water table is hundreds of meters below the reference repository horizon. Lawrence Livermore National Laboratory (LLNL) is developing designs for waste packages and testing the performance of waste forms and metal barriers under expected repository conditions for the YMPO Project.

The Environmental Protection Agency (EPA) (1) and the Nuclear Regulatory Commission (NRC) (2) have imposed requirements 1 imiting potential radionuclide release from a high-level nuclear waste repository. Studies $(3,4)$ are under way at Pacific Northwest Laboratory (PNL) (a) to determine whether the spent fuel waste form helps meet these requirements by retarding the release of the radionuclides. The majority of spent fuel rods placed in a repository will consist of fragmented $\mathrm{UO}_{2}$ pellets enclosed by intact Zircaloy cladding. A small fraction of the rods may have cladding defects, usually in the form of small splits or pinholes. (5) The spent fuel itself retards the release of some radionuclides, and the cladding provides a barrier by limiting the ingress of water to the fuel and the egress of radionuclides.

The potential change in the oxidation state of spent fuel during its residence in a repository must be known to evaluate its radionuclide retention capabilities. Analysis $(6)$ of the standard free energies of the uranium oxides indicates that $\mathrm{UO}_{2}$ may oxidize to higher states under the temperature and atmospheric conditions expected in a tuff repository. Further analyses also indicate that there will be sufficient air in the repository, at least initialiy, to exceed the equilibrium pressure necessary for the reactions. If the oxidation progresses far enough, the condition of the spent fuel could change,

(a) Operated for the U.S. Department of Energy by Battelie Memorial Institute under Contract DE-AC06-76RLO 1830. 
affecting its ability to retain radionuclides. Swelling due to oxide formation may cause splitting of previously breached cladding, or significant quantities of higher oxides with potentially higher leach rates might form.

\subsection{OBUECTIVE OF THERMOGRAVIMETRIC ANALYSIS TESTING}

A technical approach(7) was developed to study spent fuel oxidation at the low temperatures characteristic of the post-container breach period. The approach, shown in Figure 1.1, is to perform tests and evaluations to gain understanding of the operative oxidation mechanisms, to obtain oxidation rate data, and to make projections of potential iony-term spent fuel oxidation

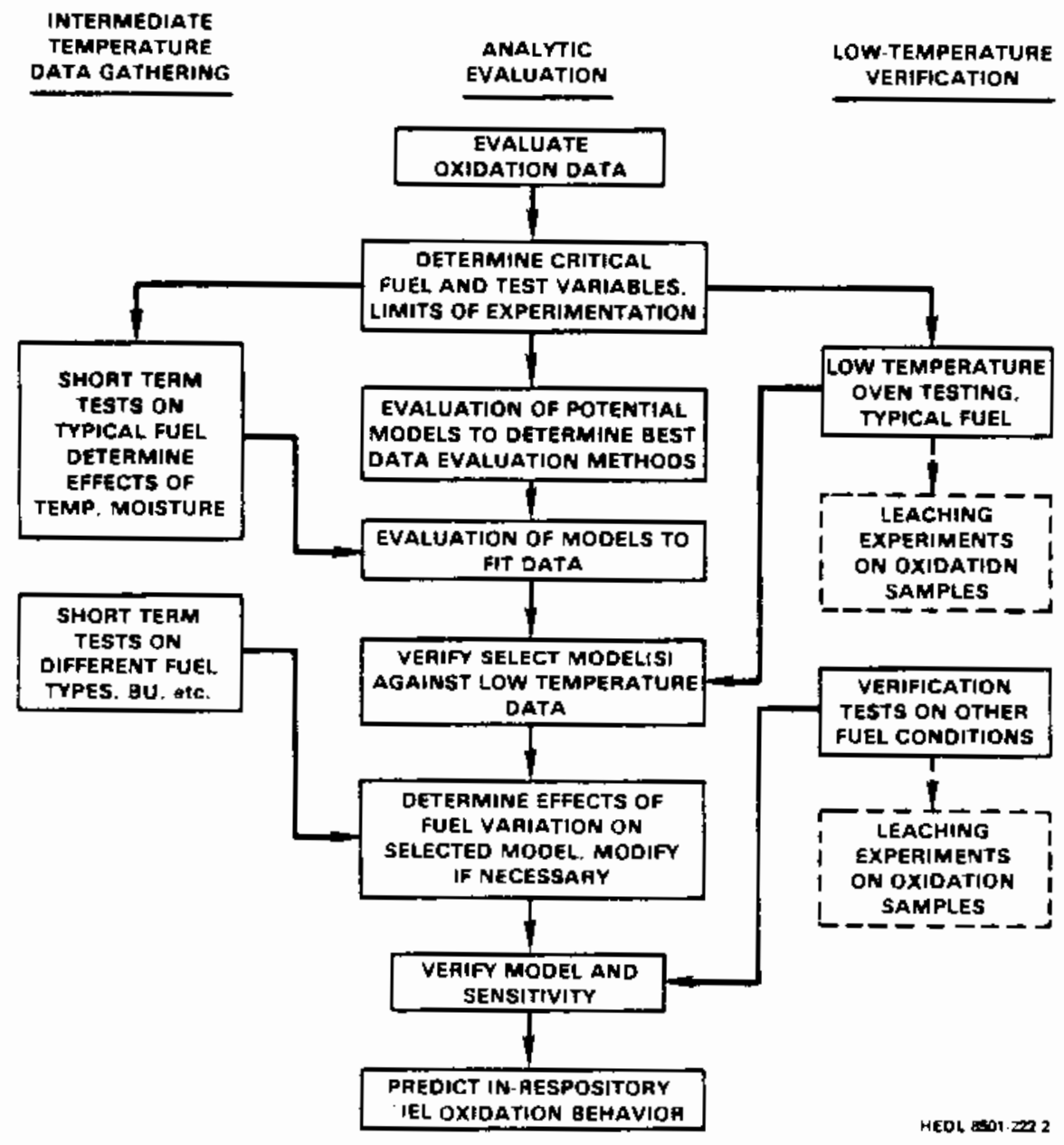

F IGURE 1.1. Technical Approach to Low-Temperature Fuel idxidation Study 
states. Time and temperature dependence of existing models are to be evaluated, and the dependence of the model projections on fuel variables will be determined. The objective of the short-term thermogravimetric analysis (TGA) is to determine, at intermediate temperatures where reaction rates are more rapid, important fuel characteristics (i.e., gas release, burnup, fuel type) and atmospheric variables (i.e., moisture content, radiation field) that affect the oxidation rate and influence the oxidation mechanism. The previous set of tests, Series 2, was designed to determine the effects of atmospheric moisture and temperature on the oxidation rate and phase formation in pressurized water reactor (PWR) spent fuel. The present series of tests are designed to determine only the temperature effects on the oxidation rate and phase formation in boiling water reactor (BWR) fuel. Grain size and particle size effects will not be investigated.

\subsection{BACKGROUND}

The spent fuel oxidation data base was extensively reviewed before the Series 2 tests. Based on the anticipated and possible atmospheres the rods might experience, several shortcomings in the data base were identified. The complete data evaluation, found in Reference 6 , is summarized below. Most $\mathrm{UO}_{2}$ oxidation data are gathered above $200^{\circ} \mathrm{C}$ and then extrapolated to lower temperatures. The data indicate little or nothing about the rate of formation of intermediate oxides, or which oxides are formed; the data usually relate to the time period before spallation resulting from the formation of $U_{3} 0_{8}$. Assuming conservatively that a container might breach between 300 and 1000 years after repository closure, the spent fuel temperature(8) will be between $160^{\circ} \mathrm{C}$ and $110^{\circ} \mathrm{C}$. There are relatively few data to indicate how rapidly $U_{4} 0_{9}$ and $U_{3} 0_{7}$ will form at temperatures between $160^{\circ} \mathrm{C}$ and $110^{\circ} \mathrm{C}$. A time-dependent extrapolation(7) of the high temperature data $(9)$ indicates that insufficient spent fuel will oxidize to $\mathrm{U}_{3} \mathrm{O}_{8}$ in 3000 years to cause disruption of the cladding. This extrapolation is predicated on the assumption that there are no additional low activation energy or athermal fuel oxidation mechanisms taking place that are insignificant at the higher test temperatures but that become dominant at the lower temperatures expected in the repository. These extrapolations are based on oxidation data from PWR spent fuel using laboratory air 
with its normal moisture content. The effect of the moisture content of the air and the validity of using PWR spent fuel oxidation data for BWR spent fuel performance predictions are unknown.

Recent oxidation studies have been performed in Canada and the United States at temperatures below $200^{\circ} \mathrm{C}$ with a ranye of moisture in the atmosphere. CANDU spent fuel, with a high linear neat rating, showed a strong enhancement of grain boundary attack in a saturated moist atmosphere ${ }^{(a)}$ at $150^{\circ} \mathrm{C} .(10)$ Gilbert et al. (11) have studied the oxidation of a variety of spent fuels over a range of burnups. In the range of 10 to $35 \mathrm{GWd} / M T U$, burnup had little effect on the oxidation rate of Quad Cities $B W R$ fuel at $230^{\circ} \mathrm{C}$. Monticello experimental BWR-rodlet spent fuel showed as inuch as $2 \%$ weight gain, equivalent to $\mathrm{J}_{3} \mathrm{O}_{7}$, in on $1 \mathrm{y} 6000 \mathrm{~h}$ at $170^{\circ} \mathrm{C}$, although the uncertainty was as much as 50\%. (11) Little difference was found between the behavior of 3 WR and PWR fuel. The efforts of that BWR study(11) and its companion PWR studies(11) were aimed more at determining powder formation applicable to dry storage than mechanisms of $\mathrm{U}_{3} \mathrm{O}_{7}$ and $\mathrm{U}_{4} \mathrm{O}_{9}$ formation applicable to repository work. These $3 W R$ and PWR studies were also conducted in a high $f 1 u x\left(5 \times 10^{5} \mathrm{R} / \mathrm{h}\right)$ imposed yamma field, which would not be present in the repository at the expected time of possible container failure.

The TGA study of Turkey Point PWR spent fuel (11) between $225^{\circ} \mathrm{C}$ and $140^{\circ} \mathrm{C}$ indicated that oxidation appears to occur by a two-stage mechanism: 1) diffusion of oxygen into and oxidation of the grain boundaries, and 2) buik oxidation of the grains by the progression of a $\mathrm{U}_{\mathrm{L}} \mathrm{O}_{9} / \mathrm{UO}_{2}$ front due to diffusion of $0_{2}$ through a layer of oxygen-saturated $\mathrm{U}_{4} \mathrm{O}_{9}$. Particie size would be unimportant if the grain boundary diffusion occurs rapidly with respect to the test duration. However, the TGA test at $140^{\circ} \mathrm{C}$ indicated that it is necessary to use puiverized fuel to obtain measurable oxidation in a reasonable length of time, since grain boundary diffusion is very slow at the lower temperatures.

(a) Reference 10 was anbiguous with respect to the meaning of saturated moist atmosphere. 
Over a range of 3 to $16,000 \mathrm{ppm}$ of $\mathrm{H}_{2} \mathrm{O}$, the moisture content of the air appears to have only a minor effect on the short-term oxidation rate of PWR fuel.(12) The rate may decrease with increasing moisture content.(12) 
,

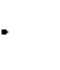




\subsection{EXPERIMENTAL DESCRIPTION}

The tests described in this test plan will be conducted in a TGA system that provides the proper atmosphere and temperature and records the sample weight gain as a function of time. The samples will come from BWR fuel rods that are being characterized by the Materials Characterization Center (MCC) at

PNL. The general procedure for oxidation tests is as follows: 1) maintain the sample under the proper environmental conditions, 2) heat the sample to the desired temperature, 3 ) determine a measure of the oxidation, usualiy weight gain or phase change, and 4) monitor the oxidation as a function of time. This can be repeated for as many sample types, environments, and temperatures as is practical. Basically, a sample, an environment, a heating source, and a response measurement are needed. After the tests are complete, the samples will be further examined by techniques such as x-ray diffraction (XRD), ceramography, transmission electron microscopy (TEM), ion-microprobe, and scanning electron microscopy (SEM). The gas mixture in the systeri will be monitored for ${ }^{85} \mathrm{Kr}$. The data will be compared with the TGA oxidation data obtained on PWR fuel(12) and long-term tests conducted in drybaths. (13)

\subsection{TEST MATRIX}

The BWR fuel oxidation test matrix as shown in Table 2.1 consists of ten subtests at five temperatures with an atmospheric dew point of $14.5^{\circ} \mathrm{C}$. Temperatures will range from 140 to $225^{\circ} \mathrm{C}$ and tests will last from 300 to $3000 \mathrm{~h}$.

The BWR fuel oxidation rate is expected to have an Arrhenius temperature behavior similar to that exhibited by the PWR fuel. It would be desirabie to have oxidation data at repository temperatures, $-100^{\circ} \mathrm{C}$, however, the $T G A$ syster cannot provide useful information in a reasonable length of time below $140^{\circ} \mathrm{C}$ because the quality of the data is marginal at best. In order to make direct comparison with the oxidation results on PWR fuel, test temperatures of 225 , $200,175,155$, and $140^{\circ} \mathrm{C}$ were chosen. These temperatures nearly equaliy divide the reciprocal temperature range of interest. 
TABLE 2.1. TGA BWR Fuel Test Matrix

\begin{tabular}{|c|c|c|c|c|c|}
\hline Test & $\begin{array}{c}\text { Nominal } \\
\text { Temperature }\left({ }^{\circ} \mathrm{C}\right) \\
\end{array}$ & Fuel & $\begin{array}{l}\text { Nominal } \\
\text { Moisture (DP) } \\
\end{array}$ & $\begin{array}{c}\text { Sample } \\
\text { Condition } \\
\end{array}$ & $\begin{array}{c}\text { Tentative } \\
\text { Test Duration }(h) \\
\end{array}$ \\
\hline$B W R-1$ & 200 & Cooper & +14.5 & fragment & 800 \\
\hline BWR -2 & 155 & Cooper & +14.5 & fragment & 2200 \\
\hline$B W R-3$ & 225 & Cooper & +14.5 & fragment & $300-600$ \\
\hline$B W R-4$ & 175 & Cooper & +14.5 & fragment & 2100 \\
\hline$B W R-5$ & 140 & Cooper & +14.5 & pulverized & 3000 \\
\hline$B W R-6$ & 225 & Cooper & +14.5 & fragment & $300-600$ \\
\hline BWR -7 & 155 & Cooper & +14.5 & fragment & 2200 \\
\hline$B W R-8$ & 200 & Cooper & +14.5 & fragment & 800 \\
\hline$B W R-9$ & 175 & Cooper & +14.5 & putverized & 2100 \\
\hline$B W R-10$ & 155 & Cooper & +14.5 & pulverized & 2200 \\
\hline
\end{tabular}

No external radiation field will be imposed on the samples. The spent fuel will be subjected to its own radiation field generated by the selfcontained fission products and actinides. This self-gamma field, depending on whether the fuel was fragmented or pulverized, ranges from 5 to $10 \%$ of the gamma field that the fuel would have seen if the fuel were in an assembly configuration but 800 to 1500 times greater than expected in 300- to 1000-yearold fuel. $(6,14,15)$ Therefore, the fragment test sample will have a self-gamma field that is over 30 times greater than that experienced by spent fuel in an assembly after 300 years. Due to the short range, limited mobility, and long half-life of the actinide elements, the alpha field is similar to that which would be expected in the repository. Therefore, no external fields are needed to simulate low-temperature repository conditions. We are aware that the higher fields in younger fuel may produce higher oxidation rates in the test fuel than would occur in spent fuel stored for 1000 years in a repository.

The test atmosphere will be $80 \% \mathrm{~N}_{2}+20 \%{ }^{18} \mathrm{O}_{2}$ with a dewpoint of $+14.5^{\circ} \mathrm{C}$. The ${ }^{18} \mathrm{O}_{2}$ atmosphere was chosen so that post-test ion-microprobe examinations can be used to distinguish between the oxidizing $18_{0}$ species and normal $16_{0}$ in the $\mathrm{UO}_{2}$. While the Canadian studies on CANDU fuel with a high linear heat rating indicated an enhancement of grain boundary oxidation in a water-saturated atmosphere relative to a dry atmosphere at $150^{\circ} \mathrm{C}$, both TGA tests on PWR fuel 
between $140^{\circ} \mathrm{C}$ and $225^{\circ} \mathrm{C}$ and drybath oxidation tests between $175^{\circ} \mathrm{C}$ and $110^{\circ} \mathrm{C}$ have shown that atmospheric moisture in the range of $\sim 3$ to $\sim 400,000 \mathrm{ppm} \mathrm{H}_{2} \mathrm{O}$ has iittle influence on oxidation rates. However, if there is a moisture effect, the oxidation rate of low-gas-release PWR fuel is reduced as the moisture level increases. Therefore, this series of tests on BWR spent fuel will only be conducted at a dewpoint of $14.5^{\circ} \mathrm{C}$; this condition is easy to establish, is the same dewpoint used in a majority of the PWR tests, and should provide an upper bound for the oxidation rate at a dewpoint of $95^{\circ} \mathrm{C}$. Tests at other dewpoints, as low as $-70^{\circ} \mathrm{C}$, can be conducted if it is deemed necessary. The effect of the moisture content of the atmosphere is being examined in a parallel series of BWR spent fuel oxidation tests using a drybath apparatus. (16)

The Series 2 TGA tests on PWR spent fuel and drybath tests on PWR spent fuel have shown that below $175^{\circ} \mathrm{C}$ the oxidation rate observed in the test and particle size are interdependent. The test duration and particle size combinations in the matrix were chosen to give measurable oxidation results. Based on the PWR fuel TGA tests, no measurable weight gain should occur on a fragment sample after $3000 \mathrm{~h}$ at $140^{\circ} \mathrm{C}$, but a pulverized sample would yield a measurable weight gain. Tests on pulverized fuel will also be conducted at $155^{\circ} \mathrm{C}$ and $175^{\circ} \mathrm{C}$ to compare the results with those from tests using fragment samples.

Tests BWR-1 through BWR-5 represent the basic BWR series and are the minimum testing needed for comparison of BWR and PWR spent fuel oxidation behavior. Given the typical scatter seen in the PWR tests, a much more convincing comparison could be made if the three replicate tests are also conducted. The matrix is predicated on the expectation that BWR and PWR fuel will behave similarly. If this turns out not to be the case, then the test matrix will have to be readjusted.

\subsection{SAMPLE PREPARATION AND IDENTIFICATION}

\subsubsection{Test Fuel Selection}

BWR fuel manufactured by General Electric and irradiated in the Cooper reactor as assembly CZ-346 was acquired by the Materials Characterization Center (MCC) for use as ATM-105. The published characteristics of the assembly are given in Table 2.2 and are thought to be representative of an average 
TABLE 2.2. Characteristics of ATM-105 Cooper BWR

Fuel from General ETectric

$\begin{array}{ll}\text { Fuel Type } & \text { BUR } 7 \times 7 \\ \text { Assembiy Identification } & \text { CZ-346 } \\ \text { Discharge Date } & (\mathrm{a}) \\ \text { Nominal Burnup } & \sim 26 \mathrm{MWd} / \mathrm{kgHM} \\ \text { Fission Gas Release } & \sim 0.6 \% \\ \text { Initial Enrichment } & 2.93 \% \\ \text { Initial Pellet Density } & 10.42 \mathrm{~g} / \mathrm{cm}^{3} \\ \text { Initial Rod Diameter } & 1.42 \mathrm{~cm} \\ \text { Cladding Material } & 2 i r c a l o y-2 \\ \text { Cladding Thickness } & 0.081 \mathrm{~cm} \\ \text { Rod Identification } & A D D-2974\end{array}$
(a) Information to be provided in a characterization
report to be released at a later date by the MCC.

burnup, low fission gas release BWR fuel. Samples for these TGA tests and companion long-term drybath tests will come from rod ADD-2974 in position 3C. The history of this rod will be described in a report shortly to be released by the MCC. The ATM-105 fuel assembly contains four types of spent fuel rods: 1) $2.93 \% 235 \mathrm{U}$ enrichment, 2) $1.94 \% 235 \mathrm{U}$ enrichment, 3) $1.94 \% 235 \mathrm{U}$ enrichment plus 4 wt\% $\mathrm{Gd}_{2} \mathrm{O}_{3}$, and 4) $2.93 \% 23 \mathrm{U}_{\mathrm{U}}$ enrichment plus $3 \mathrm{wt}_{\%} \mathrm{Gd}_{2} \mathrm{O}_{3}$. The rod that will be used for these oxidation tests is of the first type; i.e., 2.93\% enriched uranium with no gadolinium.

The MCC will characterize the rods. Before cutting, the rods will be punctured for both chemical and isotopic fission gas sampling. Gross and spectral gamma scanning will be used to determine the burnup profile. Burnup analyses will be conducted at three locations in the bottom half of the rod. Transverse and longitudinal ceramography examinations will be done adjacent to the burnup samples to determine grain size and look for unusual features.

After the cladding is stit, 10 to 20 fragments of $200 \mathrm{mg}$ or less each will be removed from one end of the rod segment and placed in a vial for 
transfer to the 325 Building for use in the TGA experiments. Further characterization by XRD, TEM, electron diffraction, and SEM will be conducted if similar examinations were not performed by MCC. A test sample will consist of either one or two fragments weighing approximately $200 \mathrm{mg}$ or, in the case of BWR-5, BWR -9 and BWR-10 tests, fuel pulverized to $-10 /+24$ Tyler mesh (i.e., 1.7 to $0.7 \mathrm{~mm}$ ). Before testing, the fragment $(\mathrm{s})$ will be photographed in order to document whether it came from the pellet surface and to determine an approximate size. The sample will be weighed to $\$ 0.01 \mathrm{mg}$ before placement in the TGA system.

\subsubsection{Sample Identification}

Each sample will be identified by the ATM number, rod number, elevation on the rod, and an assigned sample identification letter. The identification would thus appear as: ATM-rod-elevation-N.

\subsection{TESTING ATMOSPHERE}

The spent fuel is expected to contact a water-saturated moist-air atmosphere after container and cladding breach in the tuff repository. The oxygen in $\mathrm{UO}_{2}$ has normal isotopic composition and is almost totally ${ }^{16} 0$. If testing were conducted in a natural air atmosphere, there would be no way to distinguish the location of the additional oxygen in the reaction product $\mathrm{U}_{2+X}$. For diagnostic purposes, a mixture of $80 \% \mathrm{~N}_{2}$ plus $20 \%{ }^{18} 0_{2}$ will be used as a testing atmosphere instead of air. Since the ion microprobe can readily distinguish ${ }^{18_{0}}$ from $16_{0}$, it is possible that post-test examination of the sample will give a clue to the location in the sample where oxidation is taking place. Before the start of the test series, the ${ }^{18} \mathrm{O}_{2}$ source will be anaiyzed to determine its purity with respect to $160_{2}$. The recirculated atmospheric flow will be approximately $500 \mathrm{cc} / \mathrm{min}$, sufficient to keep an ample $0_{2}$ supply around the sample and yet not cause buoyancy effects or undue vibration to the sample.

In a repository 1000 years after closure, an atmosphere with a dewpoint near $95^{\circ} \mathrm{C}$ may be encountered. The highest dewpoint achievable in the TGA system is $20^{\circ} \mathrm{C}$ because the whole TGA microbalance is not in a thermostatically controlled environment. The moisture level will be maintained by a 
refrigerated bath, which circulates a coolant through coils surrounding a trap that contains the water source. The trap temperature, which is monitored continuously, establishes the dewpoint of the gas flowing through the trap.

\subsection{THERMOGRAVIMETRIC ANALYSIS SYSTEM}

A TGA apparatus consists of a system to establish a controlled atmosphere with the correct moisture content, a furnace to heat the sample, and an analytical balance to weigh the fuel sample continuously while it is at temperature in the furnace (see Figure 2.1). The apparatus is excellent for continuously measuring small weight changes resulting from oxidation. The samples must be

weighed before and after testing to confirm the measured weight change.

Spent fuel oxidation testing to date using a unit of this type has shown excellent temperature and weighing stability for periods up to $2100 \mathrm{~h}$, possibly due to neutralization of static charges by the ionizing radiation field. The stability can probably be maintained for longer periods of time. The furnace can be controlled to $\pm 1^{\circ} \mathrm{C}$ at temperatures up to $300^{\circ} \mathrm{C}$. There are 7 imitations on the sample size, moisture content in the atmosphere, and radiation field that the unit is capable of accommodating. The radiation limits in the open hood limit the sample size to no more than $200 \mathrm{mg}$ of spent fuel, which is equivalent to an average spent fuel fragment. A weight change of $0.01 \%$, equivalent to $20 \mu \mathrm{g}$ is well above the stability and sensitivity limits of the microbalance. A complete sample conversion to $\mathrm{U}_{3} \mathrm{O}_{7}$ amounts to $2 \%$ or $4 \mathrm{mg}$. The system can accommodate only one sample at a tine.

All measurement instrumentation (i.e., balances, thermocouples, and data recorders) will be calibrated against National Institute of Standards and Technology (NIST) traceable reference standards such as voltage, mass, or melting points. Calibration records, along with either copies of the calibration procedures or traceable reference to the calibration procedures, will be included in the data package for this test series. The frequency of calibration will be at the discretion of the principle investigator, but as a minimum at least prior to and after the test series. 


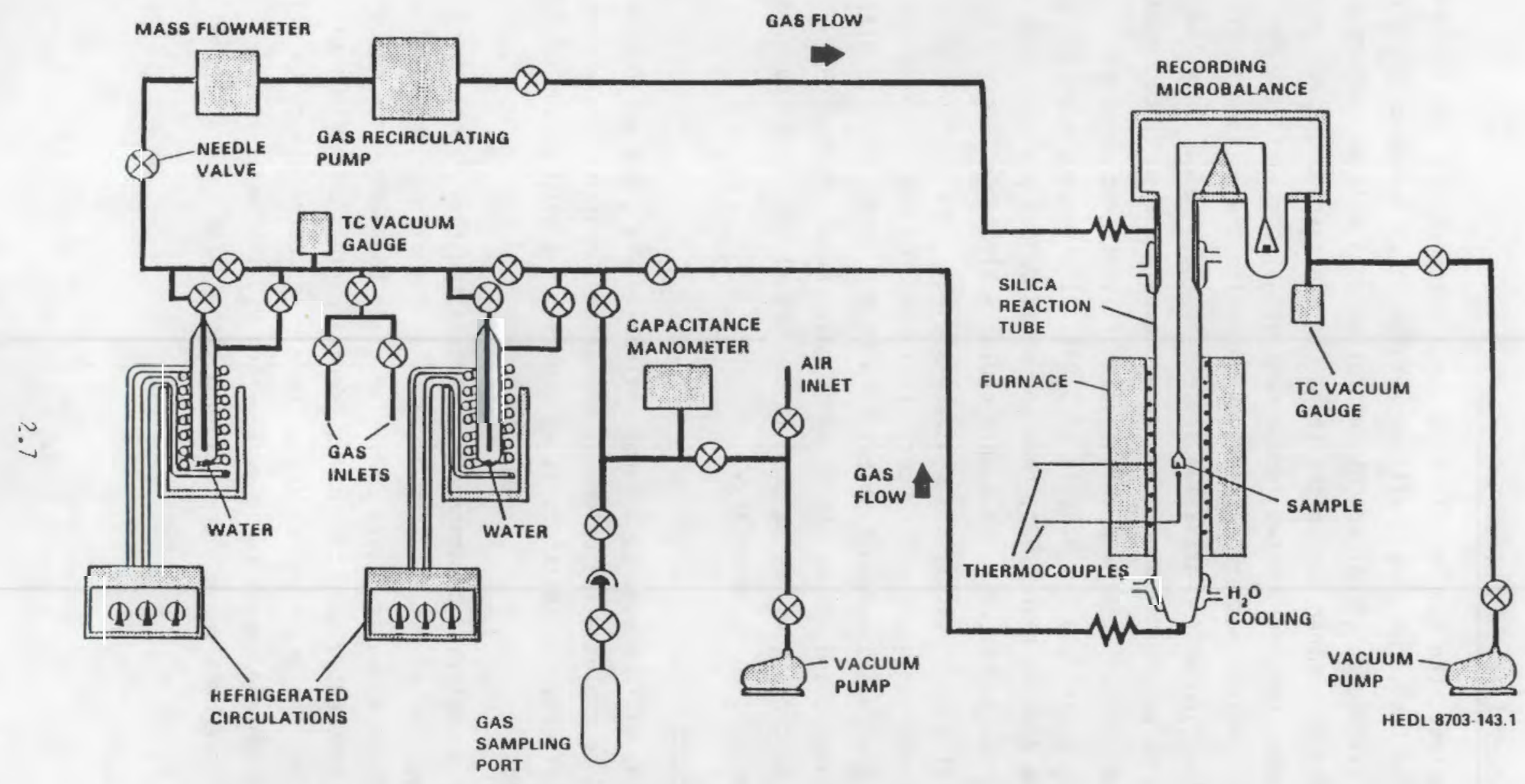

FIGURE 2.1. Schematic of TGA System 


\subsection{POST-TEST SAMPLE AND GAS EVALUATION}

During the test, the sample will be weighed automatically and continuously. After the test, the sample will be weighed on an independent balance and the weight difference (final weight-initial weight) will be compared with the weight change determined during the test. In the past, there has been excellent agreement between the two independent weight checks in the PWR fuel oxidation tests. Weight measurements cannot determine the uniformity of oxidation or the location of the oxidation process in the sample. Only limited information can be determined about the oxide phases. For instance, complete conversion of $\mathrm{UO}_{2}$ to $\mathrm{U}_{3} \mathrm{O}_{7}$ yields a weight gain of $1.98 \%$, and complete conversion to $\mathrm{U}_{3} \mathrm{O}_{8}$ yields a weight gain of $3.96 \%$. If the sample weight gain were found to be greater than $1.98 \%$, then one would probably assume that at least some $\mathrm{U}_{3} \mathrm{O}_{8}$ had formed, but the sample could be almost uniformly $\mathrm{U}_{3} \mathrm{O}_{7}$ with a minor amount of $\mathrm{U}_{3} \mathrm{O}_{8}$ or partly $\mathrm{UO}_{2}$ and partly $\mathrm{U}_{3} \mathrm{O}_{8}$. In all likelihood, some of all three phases would probably occur. Following the test, the samples selected will be examined ceramographically, with SEM, TEM, electron diffraction, ion microprobe, and XRD to obtain additional phase information. 0ther, more experimental techniques may be used if the established techniques indicate that further examination is necessary.

\subsubsection{Ceramography}

Ceramography will be used to determine visually the gross grain boundary degradation and to evaluate the extent of the oxidation into the fragment from the external surfaces. In addition, it will serve as a sampling guide for taking TEII specimens.

Typically, as-polished ceramography of irradiated fuel reveals very little grain structure. The as-polished ceramographs of the oxidized PWR fuel were quite different, as shown in Figure 2.2. The grain boundaries are quite noticeable and widened; within the grains there are rings of various thicknesses paralleling the grain boundaries. These rings correlate quite well with the TEM examination and appear to be oxygen-rich $\mathrm{U}_{4} \mathrm{O}_{9}$. The as-polished ceramography of the BWR fuel will be examined closely for both of these features. 
(a)

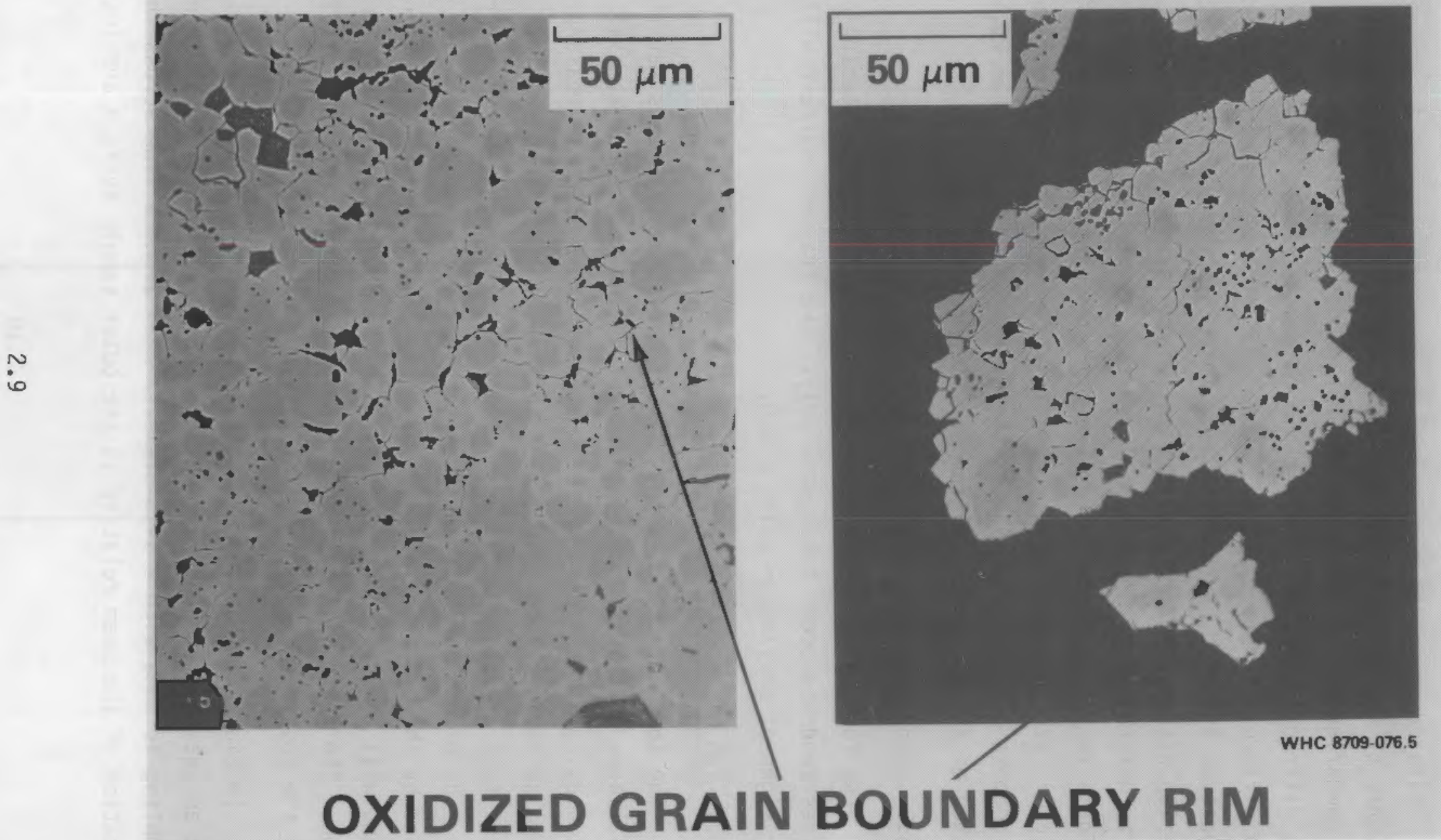

FIGURE 2.2. As-Polished Ceramography of Oxidized Fuel Showing Widened Grain Boundaries and Oxidized Fuel Runs: a) Run 15 at $175^{\circ} \mathrm{C}$, b) Run 1 at $225^{\circ} \mathrm{C}$ 


\subsubsection{X-Ray Diffraction}

$X$-ray diffraction can be used to determine semiquantitatively the relative amounts of the various phases that are present. The oxide state is determined by comparing the diffraction pattern against standard patterns. Unfortunately the diffraction patterns of certain oxides such as $\mathrm{U}_{3} \mathrm{O}_{7}$ and $\mathrm{U}_{4} \mathrm{O}_{9}$ are similar and difficult to separate, thus complicating interpretation of the patterns. Usually a standard, such as silver, which has diffraction lines that do not overlap with those of the various uranium oxides, is included in the sample. $x$-ray diffractometers sample an area that is much greater than one grain, so no information can be obtained on the oxide distribution. Careful XRD analysis is vital if accurate estimates of the relative amounts of the various oxides are to be obtained, especially when the weight gain is less than $2 \%$. The preferred method of XRD utilizes fuel samples prepared by grinding.

\subsubsection{Scanning Electron Microscopy}

LWR fuel tends to fracture intragranularly, but spallation of the higher oxides tends to occur intergranularly. The fragment surface will be examined for signs of spallation using a SEM.

\subsubsection{Ion Microprobe}

The ion microprobe, using ${ }^{16} \mathrm{O}_{2}$ primary beam, sputters material from a small area on the surface of the sample. The sputtered material is then analyzed using a mass spectrometer. It can thus be used to measure the ${ }^{18} 0 /{ }^{16} 0$ ratio at various locations on the surface of a polished sample. The oxides in spent fuel are composed of uranium and normal oxygen, which is predominantly 160. By oxidizing the spent fuel samples in a mixture of $\mathrm{N}_{2}$ and ${ }^{18} \mathrm{O}_{2}$, the ${ }^{18} 0$ added by the oxidation process can be identified by the ion microprobe. Point scans will be used to try to determine the ${ }^{18} 0 /{ }^{16} 0$ ratio as a function of position. The ratio will help to determine the location of the oxidized surfaces and the possible oxide composition, i.e., $\mathrm{U}^{16} \mathrm{O}_{2}{ }^{18} 0_{\mathrm{X}}$.

Initial examinations of two PWR fuel samples have yielded mixed results, and as yet the technique can only be considered experimental in nature. Spot sampling is done with a $6-\mu \mathrm{m}$-diameter beam along a line across the sample. The location of the beam relative to the outer sample surface and local grain 
boundary are carefully noted. The results of one such line scan from oxidized PWR fuel are shown in Figure 2.3. It seems to clearly indicate more oxidation on the grain boundaries as opposed to the grain interior. It also seems to indicate the presence of higher oxides such as $\mathrm{UO}_{3}$ and $\mathrm{U}_{3} \mathrm{O}_{8}$ on the grain boundaries, but this interpretation is not conclusive when the results from the electron diffraction and XRD measurements are analyzed.(12) Diffusional interchange of the 180 and 160 may be confusing the interpretation of the ratio of $18_{0} /\left(16_{0}+18_{0}\right)$, which could theoretically approach 1 if there were complete exchange of the oxygen initially in the fuel with the $18_{0}$ in the TGA atmosphere.

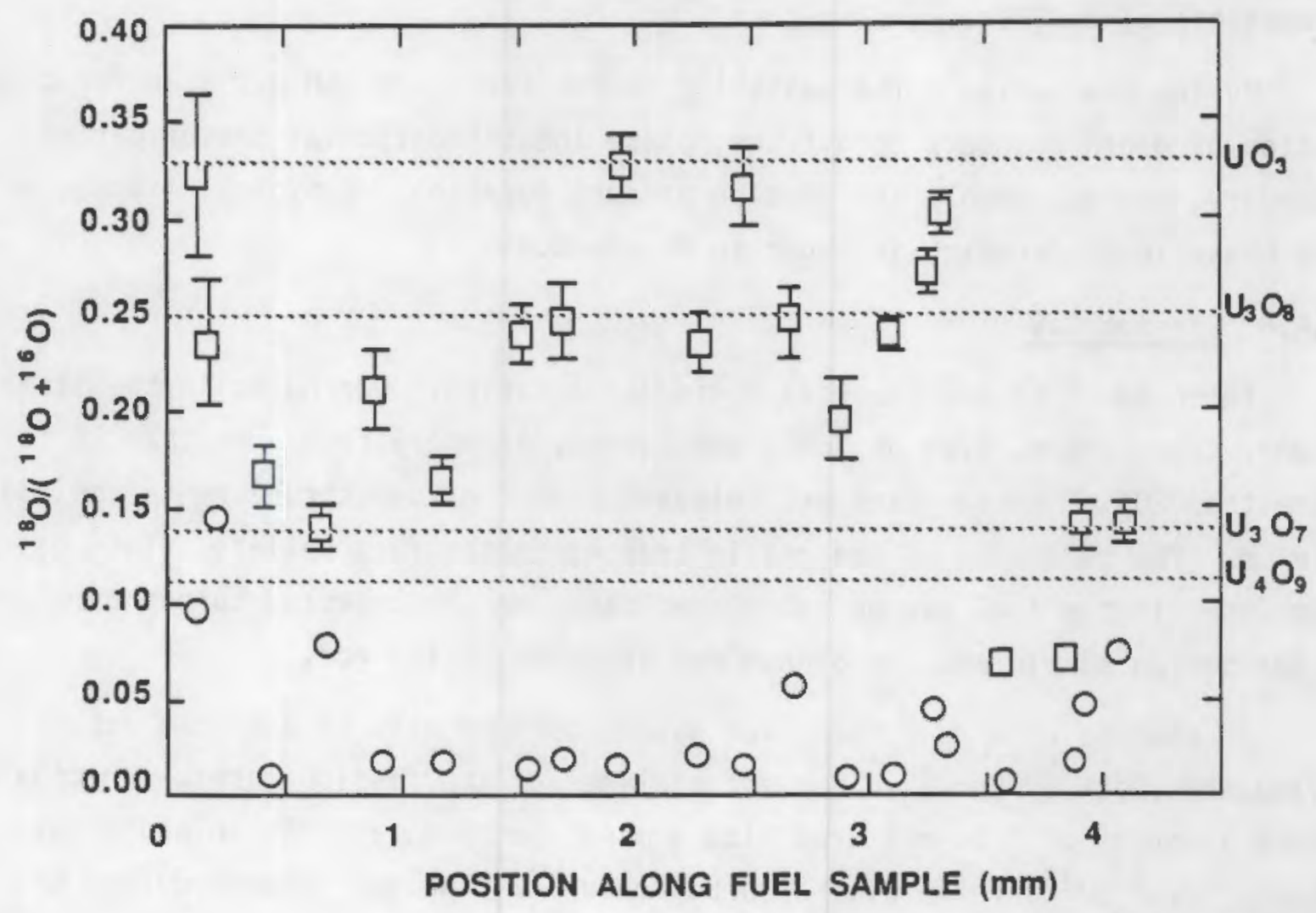

WHCM $8709-076.2$

FIGURE 2.3. 180 Distribution in PWR Fuel oxidized at $175.6^{\circ} \mathrm{C}$. Squares are at grain boundaries and circles are at grain centers. 


\subsubsection{Transmission Electron Microscopy and Electron Diffraction}

The TEM characterizes the oxidation microstructure on nearly an atomic scale. It reveals local microstructure, chemistry, and crystallography of higher oxide phases that form as oxidation proceeds. It also provides information on the chemical nature and distribution of fission products in the fuel.

Particles 200 to $400 \mu \mathrm{m}$ in diameter are chipped from the sample and embedded in epoxy within a small washer. The washer is thinned by grinding and ionmilling to produce a suitable sample. Examination is conducted in a 200-kV TEM using a small spot size. Selected area and microbeam electron diffraction are used for phase identification, diffraction contrast and atomic lattice imaging for microstructural observation and energy-dispersive $x$-ray spectrometry for compositional analysis.

During the Series 2 TGA tests(12) on PWR fuel, the TEM was used for observation of grain boundary conditions, phase identification at the oxidation boundary, and gas bubble and fission product location. A typical example of the phase identification is shown in Figure 2.4.

\subsubsection{Fission Gas}

Xenon and ${ }^{85} \mathrm{Kr}$ are produced during irradiation. Depending on the linear power, temperature, type of fuel, and burnup, anywhere from less than $1 \%$ to more than $20 \%$ of these gases are released from the fuel structure to the rod plenum. The remainder of the gas is trapped in the fuel pellets. This gas entrained in the fuel can be calculated based on the measured burnup of a characterization sample and the plenum gas analyses of the rod.

At the end of a run, the cover gas atmosphere will be expanded into an evacuated flask of known volume for analyses of the fission gases. Krypton and xenon isotopes will be measured with a mass spectrometer. As an additional check, the $180 / 160$ ratio will also be measured. The gas release during the oxidation can be determined from the calculated gas entrained in the spent fuel and the fission gas measured after the oxidation test.

Fission gas released from the PWR spent fuel during TGA oxidation tests was generally less than $1 \%$. This was expected, since no bulk $\mathrm{U}_{3} \mathrm{O}_{8}$ was found and hence there was no lattice disruption to release the gas. oxidation to 

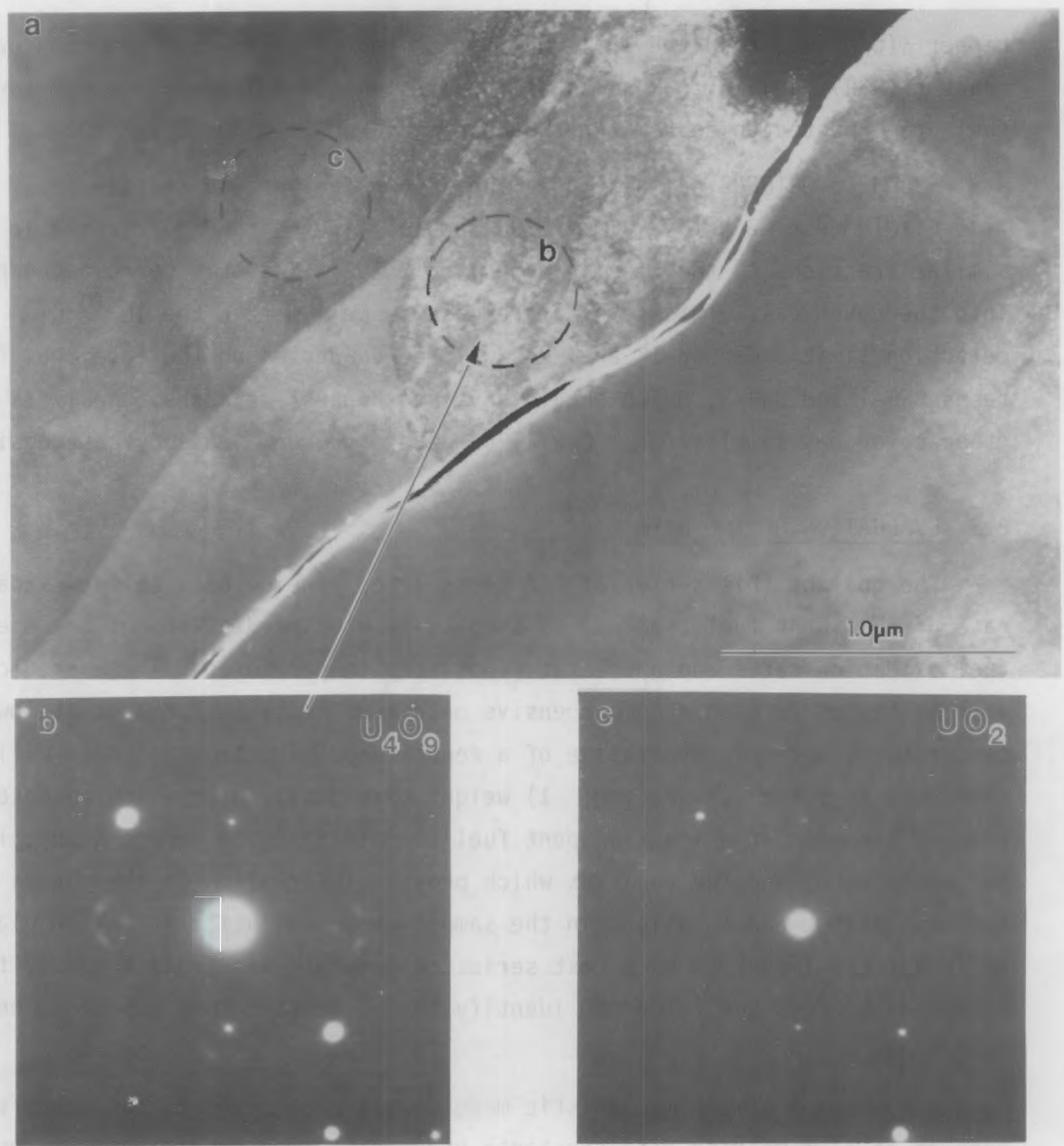

FIGURE 2.4. Grain Boundary Region in Oxidized Fuel. Sample G7-14-3-\#8 ( $155^{\circ} \mathrm{C}$ test, $0 / M=2.05$ ). (a) Darkfield TEM taken with diffuse-scattered intensity from $\mathrm{U}_{4}{ }_{9}$, showing enhanced intensity from $\mathrm{U}_{4} \mathrm{O}_{9}$ on one side of grain boundary. Only one side of the grain boundary could be imaged at a time. (b) Selected-area diffraction pattern from $\mathrm{U}_{4} \mathrm{O}_{9}$ region in (a), showing diffuse scattering from shortrange ordered oxygen interstitials. Near [001] orientation. Arrow indicates aperture position used to form darkfield image (a). (c) Selected area diffraction (SAD) pattern from $\mathrm{UO}_{2}$ region in (a). Same crystal orientation as (b). 
higher $\Delta(0 / M)$ has resulted in large fission gas releases from advanced gas reactor (AGR) fuel. (17) Results of the fission gas releases from BWR spent fuel are expected to be similar to those measured from PWR spent fuel.

Based on ORIGEN2 calculations, the Cooper fuel should contain $\sim 1.5 \mathrm{Ci} /$ MTHM, or $\sim 3 \times 10^{-7} \mathrm{Ci}$ per TGA sample. If the ${ }^{14} \mathrm{C}$ is released in similar fractions to the fission gases, $\sim 3 \times 10^{-9} \mathrm{Ci}$ should be released per run into the cover gas. This level of release is well within the $10^{-10} \mathrm{Ci}$ detection limit. Carbon-14 analyses will be conducted on the cover gas from tests BWR-1 and BWR-3, which should have the highest releases. Analyses of other cover gas samples for ${ }^{14} \mathrm{C}$ will be determined on a case by case basis.

\subsection{EVALUATION OF THE DATA}

The goal of this series of TGA tests is to provide data on the oxidation rate of BWR spent fuel that can be used to develop predictions of the spent fuel oxidation rates and phases at repository temperatures. These predictions will be tested in a more comprehensive matrix of tests in furnaces at lower temperatures more representative of a repository. Two types of data will be available from the TGA testing: 1) weight gain data, which allows a determination of the rate at which the spent fuel is oxidizing, 2) ceramography, TEM, ion microprobe, and XRD analyses which provide information on the phases that are developing, and locations in the sample where oxidation is taking place. It is not the intent of this test series to generate independent models for the oxidation process but rather to identify the mechanisms that appear to be operating.

A number of simple mechanistic models will be applied to the data for the purpose of 1) comparing rate constants under different conditions, 2) comparing PWR versus BWR fuel, and 3 ) determining the effect of experimental uncertainty on repository predictions.

Examination of the ceramography, ion-microprobe, and TEM data from the PWR samples of Series $2^{(12)}$ reveals that oxidation may be occurring by rapid diffusion along the grain boundaries followed by slow bulk diffusion through a layer of oxygen-saturated $\mathrm{U}_{4} \mathrm{Og}$. When the data was fit to a model of diffusion through a layer as the rate-controlling step (see Figure 2.5 ), there was an 


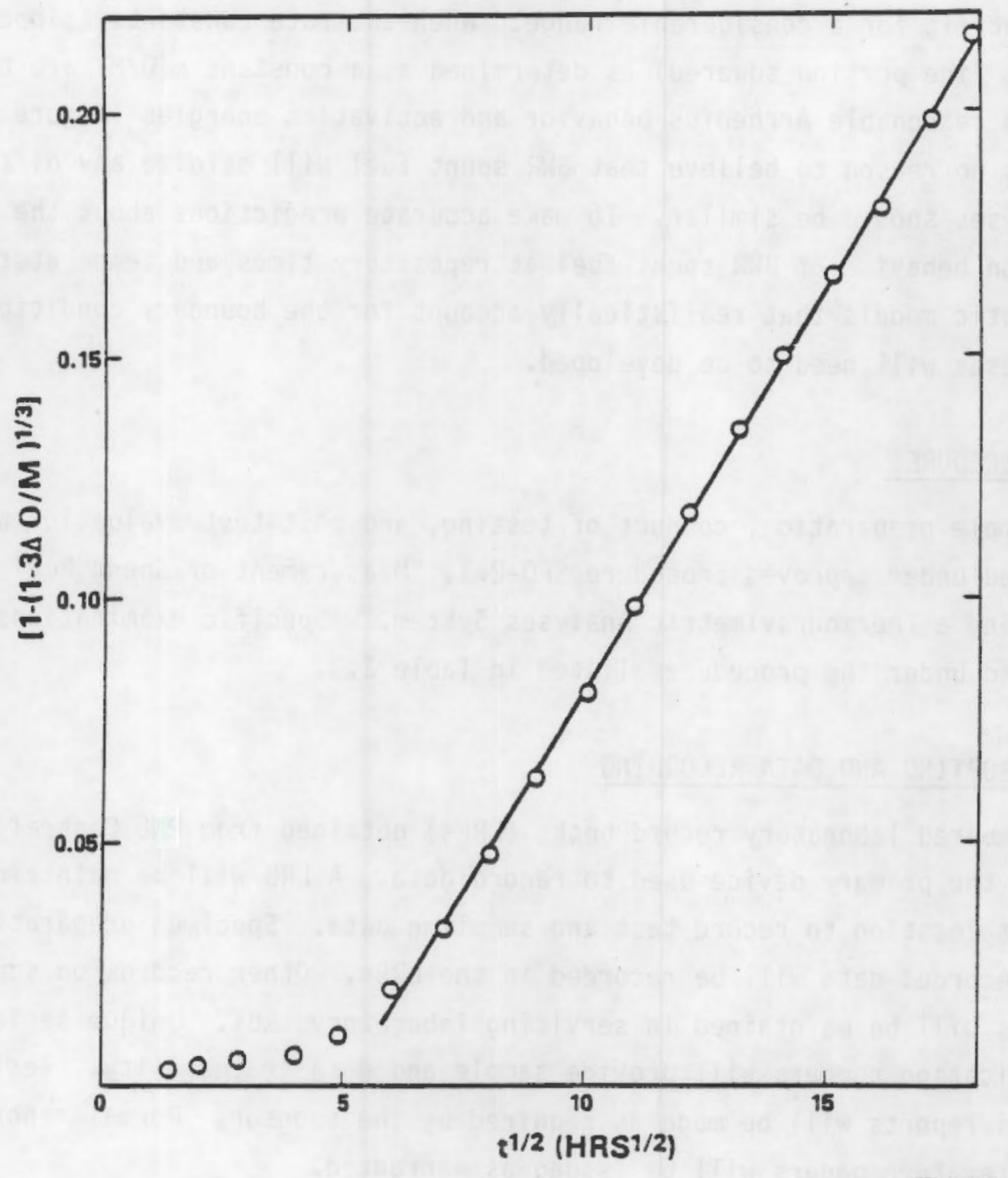

FIGURE 2.5. Oxidation of Spent Turkey Point PWR Fuel in Air at $200^{\circ} \mathrm{C}$. Measurement error on the data is less than $\pm 5 \%$ at any point. If diffusion through a layer of $\mathrm{UO}_{2}$ oxidized to the composition of $\mathrm{U}_{3} \mathrm{O}_{7}$ is rate controlling, then the plot of $\left[1-(1-3 \Delta(0 / M))^{1 / 3}\right]$ vs $t^{1 / 2}$ should be a straight line with the slope being the square root of the rate constant. 
excellent fit for a considerable range. When the rate constants (slope of the straight line portion squared) as determined at a constant $\Delta(0 / M)$ are compared, there is reasonable Arrhenius behavior and activation energies (Figure 2.6). There is no reason to believe that BWR spent fuel will oxidize any differently, so analyses should be similar. To make accurate predictions about the oxidation behavior of BWR spent fuel at repository times and temperatures, mechanistic models that realistically account for the boundary conditions in these tests will need to be developed.

\subsection{PROCEDURES}

Sample preparation, conduct of testing, and post-test evaluation will be conducted under approved procedure SF0-2-1, "Measurement of Spent Fuel 0xidation Using a Thermogravimetric Analyses System." Specific examinations will be conducted under the procedures listed in Table 2.3.

\subsection{REPORTING AND DATA RECORDING}

Numbered laboratory record books (LRBs) obtained from PNL Central Files will be the primary device used to record data. A LRB will be maintained at the test location to record test and sampling data. Specimen preparation and other recorded data will be recorded in the LRBS. Other records on sample analyses will be maintained in servicing laboratory LRBs. Unique serial sample identification numbers will provide sample and data traceability. Periodic progress reports will be made as required by the sponsor. Formal reports and open literature papers will be issued as warranted. 


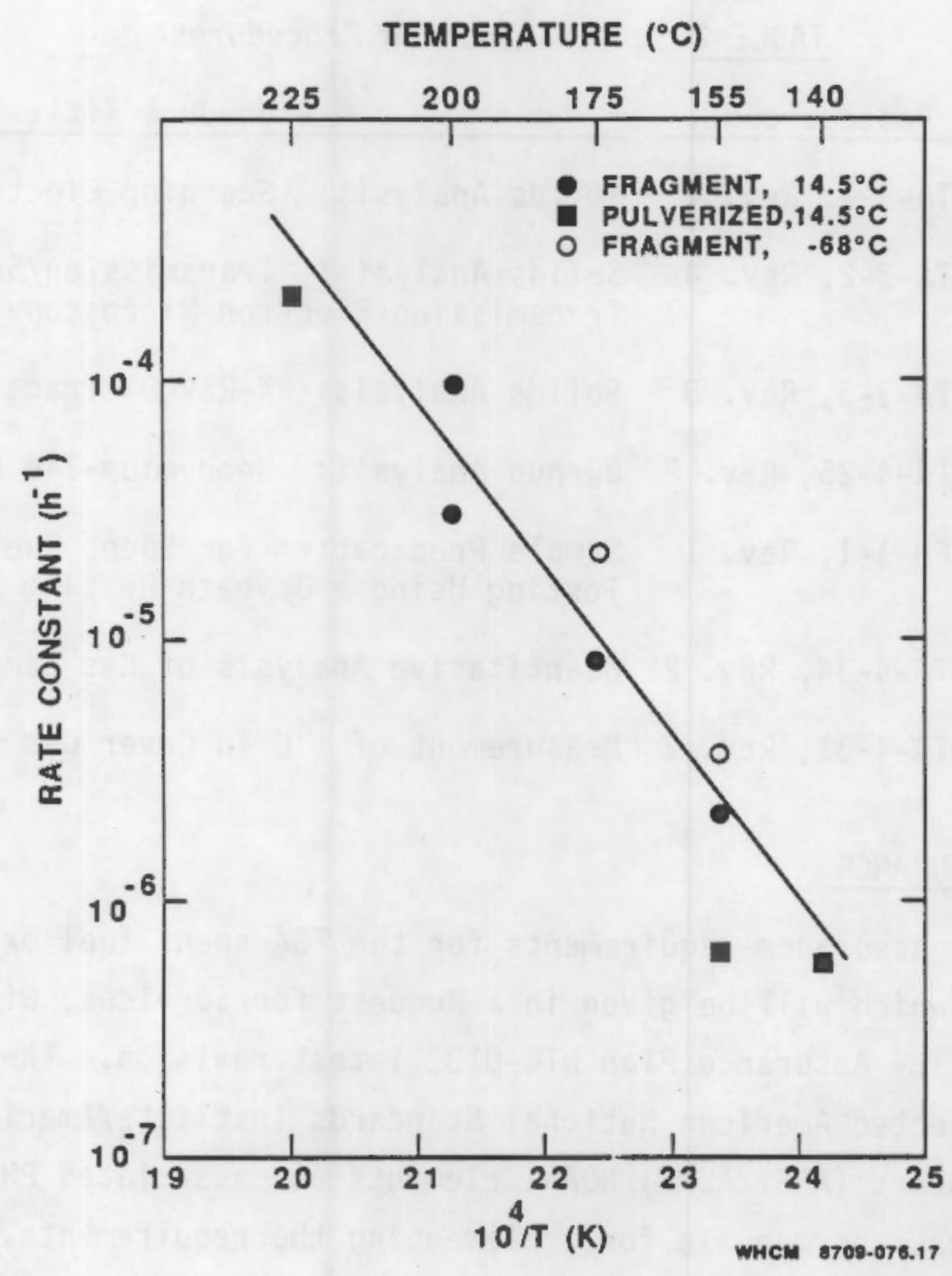

FIGURE 2.6. Arrhenius Plot at $\Delta(O / M)=0.02$ for 0xidation of PWR Fuel 


\section{TABLE 2.3. Examination Procedures}

Examination

SEM

TEM

XRD

Burnup

Ceramography

Gas Analysis

${ }^{14} \mathrm{C}$
Procedure Title

HTA-3-1, Rev. 4 Solids Analysis: Scanning Electron Microscopy

HTA-3-2, Rev. 4 Solids Analysis: Transmission/Scanning

Transmission Electron Microscopy

HTA-3-3, Rev. 3 Solids Analysis: X-Ray Diffraction Analysis

HTA-4-25, Rev. 2 Burnup Analysis: Neodymium-148 Method

SF0-1-1, Rev. 1 Sample Preparation for Spent Fuel Oxidation

Testing Using a Drybath Heating System

HTA-4-34, Rev. 2 Quantitative Analysis of Gas Samples

HTA-4-31, Rev. 2 Measurement of ${ }^{14} \mathrm{C}$ in Cover Gas

\subsection{QUALITY ASSURANCE}

The quality assurance requirements for the TGA spent fuel oxidation testing activities, which will be given in a Request for Services, will be presented in a Quality Assurance Plan WTC-018, latest revision. The QA plan will identify the selected American National Standards Institute/American Society of Mechanical Engineers (ANSI/ASME) NQA-1 elements and associated PNL instructions, procedures, and manuals for implementing the requirements. The QA plan will be transmitted in writing to LLNL. 


\subsection{REFERENCES}

1. Federal Register, EPA Final Rule, "Environmental Standards for the Management and Disposal of Spent Nuclear Fuel, High Level and Transuranic Wastes; Final Rule," Vol. 50, No. 180, September 29, 1985, (cited as 40 CFR 191).

2. Federal Register, "Disposal of High-Level Radioactive Wastes in Geologic Repositories - Licensing Procedures," Title 10, Chapter 1, Part 60, June 30,1983 , (cited as 10 CFR 60).

3. C. N. Wilson. October 1984. Test Plan for Series 2 Spent Fuel Cladding Containment Credit Tests. HEDL-TC-2353-3, Hanford Engineering DeveTopment Laboratory, Richland, Washington.

4. H. D. Smith. JuTy 1984. Zircaloy Cladding Corrosion Degradation in a Tuff Repository-Initial Experimental Plan. HEDL-7455, Hanford Engineering Development Laboratory, Richland, washington.

5. R. E. WoodTey. October 1983. The Characteristics of Spent LWR Fuel Relevant to Its Storage in Geologic Repositories. HEDL-TME-83-28, Hanford Engineering Development Laboratory, Richiand, Washington.

6. R. E. Einziger and R. E. Woodley. March 1985. Evaluation of the Potential for Spent Fuel Oxidation Under Tuff Repository Conditions. HEDL-7452, Hanford Engineering Development Laboratory, Richland, Washington.

7. R. E. Einziger. June 1985. Technical Test Description of Activities to Determine the Potential for Spent Fuel oxidation in a Tuff Repository. HEDL -7540, Hanford Engineering Development Laboratory, Richland, Washington.

8. W. Stein, J.N. Hockman, and W. C. O'Neal. 1984. Thermal Analyses of NNWSI Conceptual Waste Package Designs. UCID-20091, Lawrence Livermore National Laboratory, Livermore, California.

9. R. E. Einziger and R. V. Strain. October 17-18, 1984. "Effect of Cladding Defect Size on the Oxidation of Irradiated Spent Fuel Below $360^{\circ} \mathrm{C} . "$ In Proceedings of International Workshop on Irradiated Fuel Storage, Toronto, Canada.

10. C. R. Frost and K. H. Wasywich. April 1987. "U0, Oxidation in Air at $50^{\circ} \mathrm{C}$ to $400^{\circ} \mathrm{C}$ and the Implications for CANDU Irradiated Fuel Dry Storage." In Proceedings of International Workshop on Chemical Reactivity of Oxide Fuel and Fission Product Release, GToucestershire, England. 
11. E. R. Gilbert, T. K. Campbell, C. K. Thornhill, and G. F. Piepel. April 1987. "Progress of Air 0xidation Tests on Spent LWR Fuel in an Imposed Gamma Field." In Proceedings of International Workshop on Chemical Reactivity of oxide Fuel and Fission Product Release, GToucestershire, England.

12. R. E. Woodley, R. E. Einziger, and H. C. Buchanan. May 1987. TGA Applied to the Oxidation of Spent PWR Fuel Between 140 and $225^{\circ} \mathrm{C}$. WHC-EP-0107, Westinghouse Hanford Company, Richland, Washington.

13. R. E. Einziger and H. C. Buchanan. May 1988. Long-Teril, Low-Temperature Oxidation of PWR Spent Fuel-Interim Transition Report. WHC-EP-0070, Westinghouse Hanford Company, Richland, Washington.

14. R. E. Einziger and R. V. Strain. April 1986. 0xidation of Spent Fuel at Between 250 and $360^{\circ} \mathrm{C}$. EPRI NP-4524, EJectrit Power Research Institute, Palo Äto, Californía.

15. R. E. Einziger and R. V. Strain. March 1985. "Low Temperature Spent Fuel Oxidation Under Tuff Repository Conditions." In Proceedings of Waste Management ' 85 , Tucson, Arizona, Roy G. Post, ed., p. 505.

16. R. E. Einziger. May 1988. Test Plan for Long-Term, Low-Temperature 0xidation of BWR Spent Fuel. PNL-6427, Pacific Northwest Laboratory, Richland, Washington.

17. M. J. Bennett, J. B. Price, and P. Wood. May 1987. Influence of Manufacturing Route and Burnup in the Oxidation and Fission Gas Release Behavior of Irradiated $\mathrm{UO}_{2}$ in $\mathrm{A} i \mathrm{r}$ at $175-400^{\circ} \mathrm{C}$. AERE R-12614, Atomic Energy Research Establishment. 


\section{DISTRIBUTIDN}

No. of

Copies

\section{OFFSITE}

10 DOE/Office of Scientific and Technical Information

13 DOE-HQ/Office of Civilian Radioactive Waste Management Forresta? Building Washington, DC 20585

ATTN: C. E. Kay, Acting Director RW-1

D. H. Alexander RW-332

J. C. Bresee RW-10

S. J. Brocoum RW-22I

V. J. Cassella RW-123

M. W. Frei RW-22

B. G. Gale RW-23

T. H. Isaacs RW-40

S. H. Kale RW-20

G. Parker RW-333

S. Rousso RW-10

J. D. Saltzman RW-20

R. Stein RW-30

24 DOE/Nevada Dperations Office

P.0. Box 98518

Las Vegas, NV 89193-8518

ATTN: M. Bl anchard, YMPO

M. Cloninger

P. K. Fitzsimmons

J. L. Fogg (12)

c. P. Gertz, $Y M P O$

MS-523 (5)

L.P. Skousen, YMPO

M. Valentine, YMPO

C. L. West

A. T. Tamura

DOE/Office of Scientific and Technical information

Science and Technology Division

P. 0. Box 62

Oak Ridge, TN 3783]

No. of

Copies

2 Argonne National Laboratory

Chemical Technology Division

9700 S. Cass Avenue, B1dg. 205

Argonne, IL 60439

ATTN: J. Bates

E. Veleckis

Battelie Columbus Laboratory

505 King Avenue

Columbus, $\mathrm{OH} 43201$

ONWI Library

0. Schweitzer

Brookhaven National Laboratory

Associated Universities, Inc.

Upton, NY 11973

Director

Center for Nuclear Waste and Regulatory Analyses

6220 Culebra Road

Drawer 28510

San Antonio, TX 78284

Director, Community Planning

City of Boulder City

P.0. Box 367

Boulder City, NV 89005

5 J. Foremaster

City of Caliente

P.0. Box 158

Caliente, NV 89008

City Manager

City of Henderson

Henderson, NV 89015

Economic Development Dept.

City of Las Vegas

$400 \mathrm{E}$. Steward Avenue

Las Vegas, NV 89101 
No. of

Copies

Community Planning \& Development

City of North Las Vegas

P.0. Box 4086

North Las Vegas, NV 89030

Comprehensive Planning Dept.

Clark County

225 Bridger Avenue, 7th Floor

Las Vegas, NV 89155

J. Fordham

Desert Research Institute

Water Resources Center

P.0. Box 60220

Reno, NV 89506

M. Miffi in

Desert Research Institute

Water Resources Center

2505 Chandler Avenue, Suite 1

Las Vegas, NV 89120

E. Ezra

MS H-02

EG\&G Energy Measurements, Inc.

P.0. Box 1912

Las Vegas, NV 89125

J. A. Cross MS-514

Fenix \& Scisson, Inc.

Las Vegas Branch

P.0. Box 93265

Las Vegas, NV 89193-3265

R. L. Bullock MS-403

Fenix \& Scisson, Inc.

101 Convention Center Drive, Suite 320

Las Vegas, NV 89109

A. E. Gurrola MS-580

Holmes \& Narver, Inc.

Energy Support Division

P.0. Box 9383.8

Las Vegas, NV 89193-3838
No. of

Copies

J. C. Calovini

Holmes \& Narver, Inc.

10] Convention Center Drive

Suite 860

Las Vegas, NV 89109

E. P. Binnail

Lawrence Berkeley Laboratory

Field Systems

B1dg. 50B/4235

Berkeley, CA 94720

66 Lawrence Livermore

Nationa 1 Laboratory

P. 0. Box 808

Livermore, CA 94550

ATTN: R. Aines

L. Ballou

W. Bourcier

$-219$

C. Bruton

B. Bryan

J. Dronkers

D. Emerson

W. Glassley

K. Jackson

J. Kass

K. Knauss

D. Lappa

W. Lin

C. Merzbacher

W. O'Connell

$\checkmark$. Oversby

C. Poppe

A. Ramirez

L. Ramspott (3)

M. Revel1i

E. Russe 11

$R$. Ryerson

W. Sawka

R. Schock

L. Schwartz

H. Shaw (17)

D. Short

R. Silva

R. Stout

H. Tewes

A. Tompson

R. Van Konynenburg

8. Viani
$L-206$

$L-219$

$L-219$

$L-206$

$L-204$

L- 204

$\mathrm{L}-204$

$\mathrm{L}-204$

L-204

$\mathrm{L}-202$

$\mathrm{L}-196$

L-20]

$L-202$

$L-195$

$L-206$

$L-231$

$\mathrm{L}-204$

$\mathrm{L}-204$

$L-206$

L -197

L -20$]$

$\mathrm{L}-202$

$\mathrm{L}-209$

$\mathrm{L}-203$

$\mathrm{L}-204$

L-204

L-396

$L-200$

$L-204$

$L-206$

$L-370$

$L-219$ 
No. of

Copies

H. Weed

A. Wijesinghe

T. Wolery

J. Yow

L. Younker

NWM Library (10)

Lincoln County Commission

Lincoln County

P.0. Box 90

Pioche, NV B9043

5 Los Alamos National Laboratory

P.0. Box 1663

Los Alamos, NM 87545

ATTN: K. Eggert

D. T. Oakley (4) J-52]

H. N. KaTia

MS -527

Los Alamos National Laboratory

101 Convention Center Drive Suite P230

Las Vegas, NV 89109

A. M. Sastry

MAC Technical Services

101 Convention Center Drive

Suite PII3

Las Vegas, NV 89109

E. Anderson

Mountain West Research-Southwest, Inc.

432 North 44 th Street, Suite 400

Phoenix, AZ 85008

2 C. Interrante

Bidg. 223/Rm A-245

National Bureau of Standards

Division 450

Gaithersburg, MD 20899

4 M. Bell MS-WFI-4-H3

U.S. Nuclear Regulatory Commission

Division of Waste Management

Washington, DC 20555
No. of

Copies

P. T. Prestholt

U.S. Nuclear Regulatory Commission

1050 East Flamingo Road

Suite 319

Las Vegas, NV 89119

Planning Department

Nye County

P.0. Box 153

Tonopah, NV 89049

2 Reynolds Electrical and Engineering $\mathrm{Co}$., Inc.

P.0. Box 89193-8521

ATTN: D. L. Fraser

MS -555

R. F. Pritchett MS-615

7 Sandia National Laboratories

P.0. Box 5800

A) buquerque, NM 87185

ATTN: T. 0. Hunter (5) Org 6310

R. W. Lynch Org 6300

S. Sinnock

2 Savannah River Laboratory

Aiken, SC 29808

ATTN: B. Kitchen Bldg. 773-4lA

J. Plodinec Bldg. 773-A,

Rm. B-120

3 Science Applications

International Corporation

101 Convention Center Drive

Suite 407

Las Vegas, NV 89109

ATTN: SAIC-T\&MSS Library (2)

M. E. Spaeth

State of Nevada

Office of the Governor

Capitol Complex

Carson City, NV 89710

ATTN: T. Hay 
No. of

Copies

4 State of Nevada

Nuclear Waste Project office

Evergreen Center, Suite 252

1802 N. Carson Street

Carson City, NV 89701

ATTN: C. H. Johnson

R. R. Loux, Jr. (3)

R. Moler

Systems Support, Inc.

P.0. Box 1432

Manassas, VA 22110

T. H. Pigford

University of California

Dept. of Nuclear Engineering

Berkeley, CA 94720

9 U.S. Geological Survey

P.0. Box 25046

421 Federal Center

Denver, CO 80225

ATTN: $\quad k$. W. Causseaux

V. W. Glanzman (6)

L. R. Hayes

R. V. Watkins

F. Divine

U.S. Geological Survey

Engineering Geology

106 National Center

12201 Sunrise Valley Drive

Reston, VA 22092

2 W. M. Hewitt

Technical Information Center

Roy $F$. Weston, Inc.

955 L'Enfant Plaza SW, Suite 800

Washington, DC 20024

J. Pope

West Valley Nuclear Services Co., inc.

Process Technology \& Testing

P.0. Box 191

West Valley, NY 14171-019l
No. of

Copies

\section{FOREIGN}

K. A. Simpson

Berkeley Nuclear Laboratories

Berkeley, Glouscestershire

GL 13 9PB, UK

Commission of the European

Communities

Rue de Ta Loi 200

B-1049 Brussels, Belgium

Jordi Bruno

Royal Institute of Technoiogy

Department of Inorganic Chemistry

S-100 44 Stockholm 70, Sweden

R. W. Forsyth

Studsvik $A B$

S-611 82 Nykoping, Sweden

Dr. Lars Werme

Svensk Karnbrans?ehantering $A B$

Box 5864

S-102 48 Stockholm, Sweden

Kaija 011 ila

Technical Research Centre of

Finland

Reactor Laboratory

Otakaari 3A

SF-02150 Espoo 15, Finland

7 Whitesheil

Nuclear Research Establishment

Atomic Energy of Canada, Ltd.

Pinawa, Manitoba ROE 1LO, Canada

ATTN: C. Davison

K. Dormuth

L. Johnson

F. P. Sargent

G. Simmons

S. Stroes-Gascoyne

$S$. Sunder 
No. of

Copies

ONSITE

DOE Richland Operations Office

D. C. Langstaff

P. H. Turner

J. J. Sutey

39 Pacific Northwest Laboratories

M. J. Apted

W. W. Ballard

H. C. Buchanan
No. of

Copies

T. T. Claudson

R. E. Einziger (20)

E. R. Gilbert

W. J. Gray

A. B. Johnson

S. C. Marschman

J. E. Mendel

P. W. Reimus

H. D. Smith

L. E. Thomas

C. N. Wilson

Technical Report Files (5)

Publishing Coordination 
.
.
.

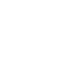

